\title{
ABSTRACT - Media Ownership and Control Law, Economics and Policy in an Indian and International Context
}

https://www.bloomsburyprofessional.com/uk/media-ownership-and-control-9781849466356/

Competition and diversity in media and communications are fundamental to a healthy economy and democracy. In India and internationally there is no consensus on the exact manner and scope of interventions that are appropriate to protect competition and pluralism in media markets.

Many emerging economies including India are seeking to adopt their own regulation in this area taking their lead from the UK. The issues have been brought into sharp focus in India in recent years. First, the enactment and implementation of modern - but sector neutral competition law under the Competition Act 2002 has caused a step change in regulation towards an economics and effects-based approach. Second, in 2013 the India telecoms regulator launched controversial reform proposals to apply a media-specific approach to ownership regulation.

As academics, lawyers, businesses, regulators and policy-makers in India cast a glance at the international experience, this book examines the legal, economic and policy issues relating to regulation of ownership and control of media markets. The focus of comparative assessment is on examples from the European Union, EU Member States and the US. 